ORIGINAL RESEARCH PAPER

\section{A STUDY AND OVERVIEW OF NON- PERFORIMING ASSETS (NPAS) ON DIFFERENT SEGIMENTS OF BANKING SECTOR IN INDIA}

\section{Commerce}

KEY WORDS: Gross

Advances, Net Advances, Banking Sector, Non-performing Assets (npas), Liberalization.

Asha

Teaching Assistant, K.S. School Of Business Management, Gujarat University, Brahmakshatriya Ahmedabad.

The current era is highly regulated to the concept of liberalization and so this era can rightly be called the era of transformation. This includes transformation of public sector to private sector and closed economy to globalized economy. This is the new starting era of new private sector banks and foreign banks. Our study is focused on gross NPA to gross advances and net NPA to net advances. Its covers the research period after the banking sector reforms started.

\section{INTRODUCTION}

It is known to all that the process of second banking reforms was going on since 1999. It has improved the performance of banks. Also many changes have occurred due to the entry of new banks into the global market. We can say that a decade of banking sector reforms has been completed. It was essential to review the various issues of banking sector reforms, especially its post reforms impact on NPAs. This study was mainly concerned with the efficacy of banking sector reforms. Here the major weak areas need to be further considered and some possible reforms need to be added in third reforms. The current study was concerned with the performance of Indian banking industry under reforms to analyze the efficacy of banking sector reforms. Six major bank groups as defined by RBI listed below were taken for the study as the universe for the study was Indian banking industry:

- Nationalized Banks

- Foreign Banks

- Old Private Sector Banks

- New Private Sector Banks

- SBI and its Associates

\section{OBJECTIVE OFTHE STUDY}

The objective of our study is to study an effective overview of Non-Performing Assets (NPAs) and its impact on different segments of the banking sector in India.

\section{RESEARCH DESIGN AND PERIOD OF THE STUDY}

Our study is mainly concerned with the post-second banking sector reforms which include the period of 2 decades right from the year 1995-96 to 2004-05 and secondly from the year 2005-06 to 2014-15.

\section{LITERATURE REVIEW}

- According to Prasad and Goyal (2015), NPA was not the factor which significantly affected the ROCE, ROA and

Table 1: Gross NPAs to Gross Advances (\% Rs. In Lakh)
RONW of Vijaya Bank. The study concluded that Vijaya Bank was effectively able to manage its NPAs. As a result, its profitability was not affected.

- According to A. Joseph and M. Prakash (2014), NPAs level was more in case of substandard asset and doubtful asset as far as the NPAs levels of the private sector banks and public sector banks were concerned. But in case of standard asset, private sector banks remain high, which shows a good position of private sector banks. It proves that the private sector banks have adopted all necessary measures in order to avoid any account becoming NPAs.

- Uppal and Khanna (2015) have analyzed the primary reasons for the growth of NPAs in scheduled commercial banks of Punjab. They have also suggested the measures for controlling them. The objectives of study were to find out the factors that affect the loan repayment capacity of the bank customers.

\section{FLUCTUATING TRENDS (GROSS NPĀS TO GROSS ADVANCES)}

After the study, it was quite clear that the percentage values of Gross NPAs to Gross Advances showed fluctuating trends in all the banks groups and years under study. It was $4.67 \%$, the least in case of new private sector banks in the entire period. The highest average decrease was by about $56 \%$ in the year of 2000-01 to 2004-05 as compared to the years 1995-96 to 19992000 in case of SBI and its associates followed by $51 \%$ in case of nationalized banks. In contradiction to that, highest increase was $102 \%$ in the case of foreign banks followed by new private sector banks with $44 \%$ where as variations in terms of CV were $47 \%$, the highest in case of SBI and its associates. In the year of 1995-96, an average percentage of Gross NPAs to Gross Advances were $9.64 \%$, which decreased to $6.59 \%$ in 2004-05. A variation in terms of $\mathrm{CV}$ was highest in the year of $1995-96$, i.e. $75.67 \%$. All the figures are in the Table No. 1 shown below.

\begin{tabular}{|c|c|c|c|c|c|c|c|c|c|c|}
\hline Sr. No & Year & $\begin{array}{c}\text { SBI and its } \\
\text { associates }\end{array}$ & $\begin{array}{c}\text { Nationalised } \\
\text { Banks }\end{array}$ & $\begin{array}{c}\text { Old Private } \\
\text { Banks }\end{array}$ & $\begin{array}{c}\text { New Private } \\
\text { Banks }\end{array}$ & $\begin{array}{c}\text { Foreign } \\
\text { Banks }\end{array}$ & RRB & Mean & SD & CV \\
\hline 1 & 2 & 3 & 4 & 5 & 6 & 7 & 8 & $10(3$ to 9$)$ & 11 & \\
\hline 1 & $1995-96$ & 13.97 & 19.86 & 8.29 & 2.53 & 3.54 & NA & 9.64 & 7.29 & 75.67 \\
\hline 2 & $1996-97$ & 15.3 & 19.89 & 8.98 & 3.75 & 8.33 & NA & 11.25 & 6.34 & 56.39 \\
\hline 3 & $1997-98$ & 15.52 & 17.69 & 10.66 & 4.89 & 13.35 & NA & 12.42 & 4.95 & 39.86 \\
\hline 4 & $1998-99$ & NA & NA & NA & NA & NA & NA & NA & NA & NA \\
\hline 5 & $1999-2000$ & NA & NA & NA & NA & NA & NA & NA & NA & NA \\
\hline 6 & $2000-01$ & NA & NA & NA & NA & NA & NA & NA & NA & NA \\
\hline 7 & $2001-02$ & 9.35 & 12.25 & 12.26 & 7.24 & 18.97 & NA & 12.01 & 4.43 & 36.85 \\
\hline 8 & $2002-03$ & 7.55 & 10.85 & 10.48 & 6.06 & 20.39 & NA & 11.07 & 5.58 & 50.47 \\
\hline 9 & $2003-04$ & 5.44 & 8.48 & 8.28 & 4.17 & 15.97 & NA & 8.47 & 4.58 & 54.10 \\
\hline 10 & $2004-05$ & 3.95 & 5.71 & 6.54 & 4.05 & 12.07 & NA & 6.59 & 3.59 & 54.46 \\
\hline Average & Mean & 10.15 & 13.53 & 9.36 & 4.67 & 13.3 & & & & \\
\hline
\end{tabular}




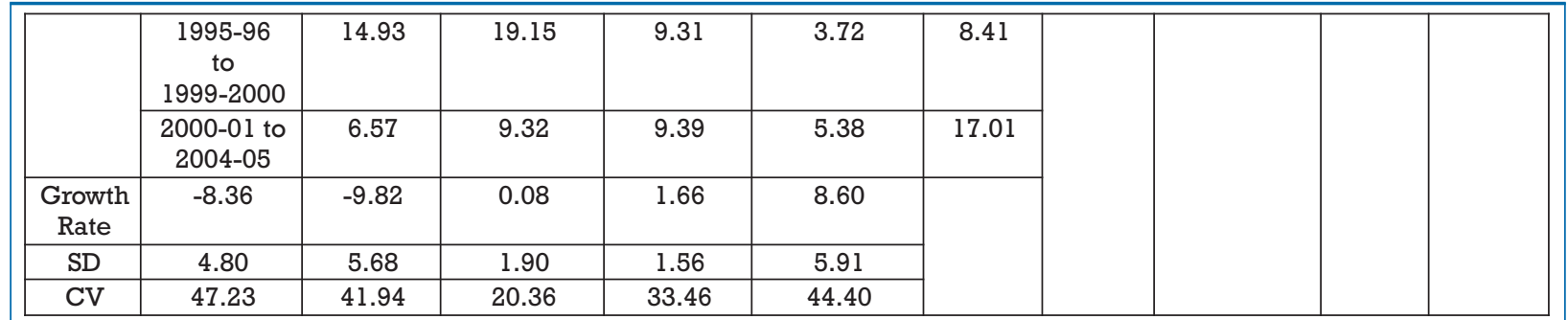

\section{FLUCTUATING TRENDS (NET NPAS TO NET ADVANCES)}

The trends in Net NPAs to Net Advances reflected the fluctuating trends in all the banks groups and years under study. It was $3.18 \%$, the least in case of new private sector banks in entire period. The highest average decreased by about $57.01 \%$ in 2000-01 to 2004-05 as compared to $1995-96$ to 1999-2000 in case of SBI and its associates followed by the

Table 2: Net NPAs to Net Advances (\% Rs. In Lakh)

\begin{tabular}{|c|c|c|c|c|c|c|c|c|c|c|}
\hline Sr. No & Year & $\begin{array}{l}\text { SBI and its } \\
\text { associates }\end{array}$ & $\begin{array}{c}\text { Nationalised } \\
\text { Banks }\end{array}$ & $\begin{array}{c}\text { Old } \\
\text { Private } \\
\text { Banks } \\
\end{array}$ & $\begin{array}{c}\text { New } \\
\text { Private } \\
\text { Banks }\end{array}$ & $\begin{array}{c}\text { Foreign } \\
\text { Banks }\end{array}$ & RRB & Mean & SD & $\mathrm{CV}$ \\
\hline 1 & 2 & 3 & 4 & 5 & 6 & 7 & 8 & 10 (3 to 9$)$ & 11 & \\
\hline 1 & $1995-96$ & 7.57 & 10.23 & 4.56 & 1.05 & 1.62 & $\mathrm{NA}$ & 15.01 & 3.91 & 78.12 \\
\hline 2 & $1996-97$ & 8.71 & 10.41 & 5.29 & 2.83 & 5.52 & $\mathrm{NA}$ & 56.55 & 3.00 & 45.82 \\
\hline 3 & 1997-98 & 8.95 & 9.21 & 6.25 & 3.40 & 6.10 & $\mathrm{NA}$ & 86.78 & 2.39 & 35.19 \\
\hline 4 & $1998-99$ & 9.22 & 8.67 & 8.02 & 4.45 & 6.40 & $\mathrm{NA}$ & 57.35 & 1.94 & 26.34 \\
\hline 5 & $1999-2000$ & 7.68 & 7.47 & 6.78 & 3.77 & 7.33 & $\mathrm{NA}$ & 16.61 & 1.62 & 24.52 \\
\hline 6 & $2000-2001$ & 6.90 & 7.56 & 7.47 & 3.49 & 7.98 & $\mathrm{NA}$ & 86.68 & 1.82 & 27.31 \\
\hline 7 & 2001-2002 & 5.11 & 6.60 & 7.22 & 4.49 & 13.04 & $\mathrm{NA}$ & 97.29 & 3.40 & 46.57 \\
\hline 8 & 2002-2003 & 3.48 & 5.04 & 5.87 & 4.00 & 9.30 & $\mathrm{NA}$ & 45.54 & 2.30 & 41.48 \\
\hline 9 & 2003-2004 & 1.22 & 3.31 & 4.04 & 2.25 & 7.57 & $\mathrm{NA}$ & 83.68 & 2.42 & 65.89 \\
\hline 10 & 2004-2005 & 1.40 & 2.19 & 2.93 & 2.06 & 3.78 & $\mathrm{NA}$ & 2.47 & 0.91 & 36.85 \\
\hline \multirow[t]{3}{*}{ Average } & Mean & 6.02 & 7.07 & 5.84 & 3.18 & 6.86 & $\mathrm{NA}$ & & & \\
\hline & $\begin{array}{c}1995-96 \\
\text { to } \\
1999-2000\end{array}$ & 8.43 & 9.20 & 6.18 & 3.10 & 5.39 & $\mathrm{NA}$ & & & \\
\hline & $\begin{array}{c}2000-01 \text { to } \\
2004-05\end{array}$ & 3.62 & 4.94 & 5.51 & 3.26 & 8.33 & $\mathrm{NA}$ & & & \\
\hline $\begin{array}{c}\text { Growth } \\
\text { Rate }\end{array}$ & 57.01 & -46.29 & -10.91 & 5.10 & 54.51 & $\mathrm{NA}$ & & & & \\
\hline SD & 3.05 & 2.81 & 1.63 & 1.12 & 3.08 & $\mathrm{NA}$ & & & & \\
\hline $\mathrm{CV}$ & 50.61 & 39.73 & 27.96 & 35.20 & 44.94 & $\mathrm{NA}$ & & & & \\
\hline
\end{tabular}

\section{FLUCTUATING TRENDS (GROSS NPAS TO GROSS}

\section{ADVANCES)}

The study revealed that the Gross NPAs to Gross Advances (\%) showed fluctuating trends in all bank groups and years under study. It was $2.21 \%$, the least in case of new private sector banks in entire period. The highest negative growth rate was about $28.22 \%$ in the year $2010-11$ to $2014-15$ as compared to the year of 2005-06 to 2009-10 in case of old private sector banks followed by new private sector banks nationalized banks with $46.29 \%$. Contradictory to that, the highest increase was $54.51 \%$ in case of the foreign banks whereas variations in terms of C.V. were highest in case of SBI and its associates with $50.61 \%$. Further, we note that in 199596, average ratio was $5.01 \%$ with $78.13 \%$ co-efficient of variations, which was reduced to half, i.e. $2.47 \%$ in $2004-05$. All the figures are in the Table No. 2 shown below.

Table 3: Gross NPAs to Gross Advances (\% Amount in Millions)

\begin{tabular}{|c|c|c|c|c|c|c|c|c|c|c|}
\hline Sr. No & Year & $\begin{array}{c}\text { SBI and its } \\
\text { associates }\end{array}$ & $\begin{array}{c}\text { Nationalised } \\
\text { Banks }\end{array}$ & $\begin{array}{c}\text { Old } \\
\text { Private } \\
\text { Banks }\end{array}$ & $\begin{array}{c}\text { New } \\
\text { Private } \\
\text { Banks }\end{array}$ & $\begin{array}{c}\text { Foreign } \\
\text { Banks }\end{array}$ & RRB & Mean & SD & CV \\
\hline 1 & 2 & 3 & 4 & 5 & 6 & 7 & 8 & 10 & 11 & \\
\hline 1 & $2005-2006$ & 3.37 & 3.92 & 4.45 & 1.67 & 1.98 & 2.50 & 3.08 & 1.21 & 39.42 \\
\hline 2 & $2006-2007$ & 2.63 & 2.74 & 3.21 & 1.92 & 1.79 & 2.23 & 2.46 & 0.59 & 24.12 \\
\hline 3 & $2007-2008$ & 2.61 & 2.07 & 2.28 & 2.54 & 1.77 & 2.51 & 2.25 & 0.34 & 15.1 \\
\hline 4 & $2008-2009$ & 2.49 & 1.75 & 2.34 & 3.10 & 3.90 & 2.94 & 2.71 & 0.82 & 30.11 \\
\hline 5 & $2009-2010$ & 2.74 & 1.97 & 2.25 & 2.93 & 4.37 & 2.79 & 2.85 & 0.93 & 32.56 \\
\hline 6 & $2010-2011$ & 3.06 & 1.92 & 1.97 & 2.37 & 2.59 & 2.29 & 2.38 & 0.47 & 19.82 \\
\hline 7 & $2011-2012$ & 4.19 & 2.55 & 1.83 & 1.98 & 2.74 & 1.94 & 2.66 & 0.94 & 35.23 \\
\hline 8 & $2012-2013$ & 4.55 & 3.30 & 2.26 & 1.82 & 3.03 & 1.84 & 2.99 & 1.05 & 35.22 \\
\hline 9 & $2013-2014$ & 5.10 & 4.20 & 1.97 & 1.79 & 3.97 & 1.83 & 3.41 & 1.46 & 42.80 \\
\hline
\end{tabular}

with $7.62 \%$. In contradiction to that, the highest increase was $96.52 \%$ in case of foreign banks followed by nationalized banks with $64.95 \%$. The variation in terms of CV was $40.46 \%$, the highest in case of nationalized banks. In the year 200506 , an average percentage of Gross NPAs to Gross Advances were $3.08 \%$, which increased to $3.57 \%$ in $2014-15$, whereas variations in terms of CV was maximum in the year of 201314 , i.e. $42.80 \%$. All the figures are in the Table No. 3 shown below. 
PARIPEX - INDIAN JOURNAL OF RESEARCH | Volume-9 | IsSue-1 | January - 2020 | PRINT ISSN No. 2250 - 1991 | DOI : $10.36106 /$ paripex

\begin{tabular}{|c|c|c|c|c|c|c|c|c|c|c|}
\hline 10 & $2014-2015$ & 4.39 & 5.42 & 2.78 & 1.99 & 3.29 & 2.15 & 3.57 & 1.35 & 37.77 \\
\hline \multirow[t]{3}{*}{ Average } & $\begin{array}{c}2005-06 \\
\text { to } \\
2014-15\end{array}$ & 3.51 & 2.99 & 2.53 & 2.21 & 2.94 & 2.30 & & & \\
\hline & $\begin{array}{c}2005-06 \\
\text { to } \\
2009-10\end{array}$ & 2.77 & 2.91 & 3.31 & 2.04 & 1.85 & 2.41 & & & \\
\hline & $\begin{array}{c}2010-11 \\
\text { to } \\
2014-15\end{array}$ & 4.26 & 4.81 & 2.38 & 1.89 & 3.63 & 1.99 & & & \\
\hline Growth & 1.49 & 1.89 & -0.94 & -0.16 & 1.78 & -0.42 & & & & \\
\hline $\begin{array}{l}\text { Growth } \\
\text { Rate (\%) }\end{array}$ & 53.78 & -64.95 & -28.22 & 7.62 & 96.52 & -17.47 & & & & \\
\hline SD & 0.96 & 1.21 & 0.79 & 0.50 & 0.94 & 0.38 & & & & \\
\hline
\end{tabular}

\section{FLUCTUATING TRENDS (NET NPAS TO NET ADVANCES)}

The trends in Net NPAs to Net Advances reflected fluctuating trends in all the bank groups and years under study. It was $0.82 \%$, the least in case of new private sector banks in entire period. The highest negative growth rate was about $49.10 \%$ in 2010-11 to 2014-15 as compared to 2005-06 to 2009-10 in case of new private sector banks followed by foreign banks with
$34.40 \%$. Contradictory to that, the highest increase was $126.74 \%$ in case of nationalized banks, whereas a variation in terms of CV was highest in case of nationalized banks with $58.75 \%$. In the year 2005-06, an average percentage of Net NPAs to Net Advances were 1.22\%, which increased to $1.63 \%$ in 2014-15, whereas variations in terms of CV was maximum in the year 201415 ,i.e.68.04\%.All the figures are in the Table No. 4 shown below.

Table 4: Net NPAs to Net Advances (\% Amount in Millions)

\begin{tabular}{|c|c|c|c|c|c|c|c|c|c|c|}
\hline Sr. No & Year & $\begin{array}{l}\text { SBI and its } \\
\text { associates }\end{array}$ & $\begin{array}{c}\text { Nationalised } \\
\text { Banks }\end{array}$ & $\begin{array}{c}\text { Old } \\
\text { Private } \\
\text { Banks }\end{array}$ & $\begin{array}{c}\text { New } \\
\text { Private } \\
\text { Banks }\end{array}$ & $\begin{array}{c}\text { Foreign } \\
\text { Banks }\end{array}$ & $\mathrm{RRB}$ & Mean & SD & $\mathrm{CV}$ \\
\hline 1 & 2 & 3 & 4 & 5 & 6 & 7 & 8 & 10 & 11 & \\
\hline 1 & $2005-2006$ & 1.63 & 1.16 & 1.73 & 0.77 & 0.83 & 1.01 & 1.22 & 0.45 & 36.37 \\
\hline 2 & 2006-2007 & 1.32 & 0.94 & 0.95 & 0.96 & 0.73 & 0.97 & 0.98 & 0.21 & 21.54 \\
\hline 3 & 2007-2008 & 1.43 & 0.77 & 0.65 & 1.19 & 0.77 & 1.09 & 0.96 & 0.33 & 34.44 \\
\hline 4 & 2008-2009 & 1.47 & 0.68 & 0.87 & 1.40 & 1.81 & 1.29 & 1.24 & 0.46 & 37.29 \\
\hline 5 & $2009-2010$ & 1.50 & 0.91 & 0.76 & 1.09 & 1.82 & 1.03 & 1.22 & 0.44 & 36.00 \\
\hline 6 & 2010-2011 & 1.49 & 0.92 & 0.49 & 0.56 & 0.67 & 0.56 & 0.83 & 0.40 & 48.87 \\
\hline 7 & 2011-2012 & 1.76 & 1.44 & 0.58 & 0.42 & 0.61 & 0.46 & 0.96 & 0.60 & 62.02 \\
\hline 8 & 2012-2013 & 2.04 & 2.00 & 0.91 & 0.45 & 1.01 & 0.52 & 1.28 & 0.71 & 55.22 \\
\hline 9 & 2013-2014 & 2.67 & 2.51 & 0.96 & 0.57 & 1.09 & 0.66 & 1.56 & 0.96 & 61.68 \\
\hline 10 & 2014-2015 & 2.23 & 3.23 & 1.41 & 0.76 & 0.54 & 0.89 & 1.6 & 1.11 & 68.00 \\
\hline \multirow[t]{3}{*}{ Average } & $\begin{array}{c}2005-06 \\
\text { to } \\
2014-15\end{array}$ & 1.75 & 1.46 & 0.93 & 0.82 & 0.99 & 0.85 & & & \\
\hline & $\begin{array}{c}2005-06 \\
\text { to } \\
2009-10\end{array}$ & 1.47 & 0.89 & 0.99 & 1.08 & 1.19 & 1.08 & & & \\
\hline & $\begin{array}{c}2010-11 \\
\text { to } \\
2014-15\end{array}$ & 2.04 & 2.02 & 0.87 & 0.55 & 0.78 & 0.62 & & & \\
\hline Growth & 0.57 & 1.13 & -0.12 & -0.53 & -0.41 & -0.46 & & & & \\
\hline $\begin{array}{c}\text { Growth } \\
\text { Rate (\%) }\end{array}$ & 38.51 & 126.74 & -12.25 & -49.10 & -34.40 & 42.73 & & & & \\
\hline SD & 0.43 & 0.86 & 0.38 & 0.33 & 0.47 & 0.28 & & & & \\
\hline $\mathrm{CV}$ & 24.60 & 58.75 & 40.94 & 40.82 & 47.28 & 33.10 & & & & \\
\hline
\end{tabular}

\section{REFERENCES}

1. Joseph, M. Prakash (2014), "A study of analyzing the trend of NPA level in private sector banks and public sector banks", Research Paper, International journal of scientific and research publications, Vol. 4, Issue. 7, page no. 1-9.

2. S. S. Prasad, P. Goyal (2015), "A study of non-performing assets and its impact on Vijaya bank performance", Research Paper, Indian Journal of Accounting, Vol.XIVII (2), page no.89-92.

3. R. K. Uppal, P. Khanna (2015), "Factors affecting NPAs of Scheduled Commercial Banks: An empirical study based in Punjab" Research Paper, Indian journal of finance,Volume.9, issue num. 2, page no. 7-16. 